\title{
4 点支持鉄筋コンクリートドーム屋根の耐力に関する解析的分析 ANALYSIS OF ULTIMATE STRENGTH OF REINFORCED CONCRETE DOMES SUPPORTED AT FOUR CORNERS
}

\author{
加藤史 郎*, 原亮**, 中澤祥二*** \\ Shiro KATO, Ryo HARA and Shoji NAKAZAWA
}

\begin{abstract}
The present paper discusses on ultimate strength of a shallow reinforced concrete domes supported at four corners. The loads for investigation are not only dead load but also approximate earthquake loads considering anti-symmetrical vertical loads caused by horizontal earthquake motions. The method is based on an elastic-plastic geometrically nonlinear analysis considering both effects of initial geometric imperfections and tensile strength of concrete. Based on the results, several important structural features are revealed. The geometric imperfection distribution similar to those caused by dead load reduces the ultimate strength, and the strength is much reduced if no tensile strength is assumed for concrete. If $40 \%$ of the shell thickness and no tensile strength are assumed respectively for the imperfections and for concrete, the ultimate strength is reduced by almost half from the perfect case. The ultimate strength interaction between dead load and earthquake loads shows the importance in design to include the anti-symmetrical load components of earthquake loads. The importance of not only stiffeners at free edges but also shell geometries of bending moment free are suggested.
\end{abstract}

Keywords : Reinforced concrete dome, Ring-type lattice model, Bearing capacity, Geometric imperfections, Earthquake loads $\mathrm{RC}$ ドーム, 環状格子モデル，耐力，形状初期不整，地震荷重

1. はじめに

鉄筋コンクリートシェル（以下 RC シェルと省略）は，先駆的技 術者・研究者 1 6)により屋根として実現されてきた。このような状 況を反映し, IASS (国際シェル空間構造学会) では設計指針 7) が 作成され，長く使用されてきた。これらの $\mathrm{RC}$ シェルは，時代的に は 1970 年以前のものが多く, 鉄骨シェル 8,9) の実現とともに建築で の実績は少なくなり, むしろ, RC シェルは産業用の構造 10 12) とし て継続的に建設されてきた経緯がある。

国内の RC シェル屋根の研究に関しては, 多くの研究者 13 18) によ り解析的あるいは実験的研究が継続されている。また, 初期の実験 的研究成果の一部として 1993 年に資料集 ${ }^{19)}$ が発刊された。特に, 近年の $\mathrm{RC}$ シェル屋根の国内の研究の多くは, 実験あるいは FEM による耐力評価に関するものが多く, 武藤ほか 20) は耐震性, 中川ほ か 21) は自由曲面 RC シェルの耐力評価の研究を進めている。一方, 国外では, Andres ほか 22)は円筒 RC シェルの近似的な終局強度評 価法を提案している。

現在，IASS では，Medwadowski ほか 26)により RC シェル屋根 の設計指針の見直しが進みつつあり, また, 日本建築学会連続体構 造小委員会においても RC シェルの耐力に関する分析が継続的 27) に進められている。このような研究活動の状況を勘案し, 先のアー チに関する論文 28 に続き, 同程度のスパン, シェル厚を想定し, 4 点支持される球状の $\mathrm{RC}$ シェルを基本形状のひとつ注1) として取り 上げ，耐力特性を分析する。固定荷重に対する耐力だけでなく，国 内の建設も勘案し, 地震荷重に対する耐力も対象とし, 近似的に仮
定した地震荷重を用いて, 形状初期不整(以下，初期不整）、コンク リートの引張強度が耐力に与える影響を分析する。

\section{2. 解析対象}

\section{1 形状, 境界条件}

対象形状を図 1 に示寸。 $\mathrm{X}, \mathrm{Y}, \mathrm{Z}$ を全体座標とし， $x, y$ はそれ ぞれシェルの端部 $\mathrm{E}$ から $\mathrm{F}, \mathrm{G}$ から $\mathrm{H}$ 一軸線に沿う長さとする。偏 平な球であり, スパン $L=L_{X}=L_{Y}=35.5 \mathrm{~m}$, ライズ $H=3.94 \mathrm{~m}$, 半開 角 $\phi=\phi_{O X}=\phi_{O Y}=25.0^{\circ}$, 曲率半径 $R=R_{X}=R_{Y}=42.0 \mathrm{~m}$, シェル厚 $t=25 \mathrm{~cm}$ である。 $\mathrm{RC}$ シェルの規模として中規模のものを設定注1)した。境 界条件はシェルの 4 隅の各要素の外周支持部（図 1 の○）がピン 支持されるものを想定する。したがって, 4 要素合計で 20 節点がピ ン支持されている。なお， 後述するように 4 辺の外周部が補剛され た場合は今後の課題としたい。

\section{2 解析方法と要素分割}

解析方法は, 既往の研究 23)で用いた有限要素解析法であり，9節 点 Heterosis 曲面要素 23 25) 注2）を用いる。図 1 のように，全体をX 方向, $\mathrm{Y}$ 方向にそれぞれ 20 分割する。厚さ方向は, コンクリート を 8 層に均等分割し，鉄筋は等価な厚さの層として扱い，上下面に $x$ 方向, $y$ 方向に 2 層ずつ配置する。全体で 12 層となる。なお, 等 分布固定荷重では点 $\mathrm{I}$ の Z 軸下向き方向, 矩形状の逆対称荷重を含 む場合では点 JのZ 軸下向き方向を変位増分点とした。

\section{3 荷重条件}

基本荷重として等分布状の固定荷重を想定する。また，地震荷重

\footnotetext{
* 豊橋技術科学大学建築・都市システム学系 客員教授・工博

** 豊橋技術科学大学建築・都市システム学系 博士前期課程 · 学生

*** 豊橋技術科学大学建築・都市システム学系 准教授・博士 (工学)
}

Prof., Dept. of Architecture and Civil Eng., Toyohashi Univ. of Tech., Dr. Eng.

Graduate Student, Dept. of Architecture and Civil Eng., Toyohashi Univ. of Tech. Assoc. Prof., Dept. of Architecture and Civil Eng., Toyohashi Univ. of Tech., Ph. D. 

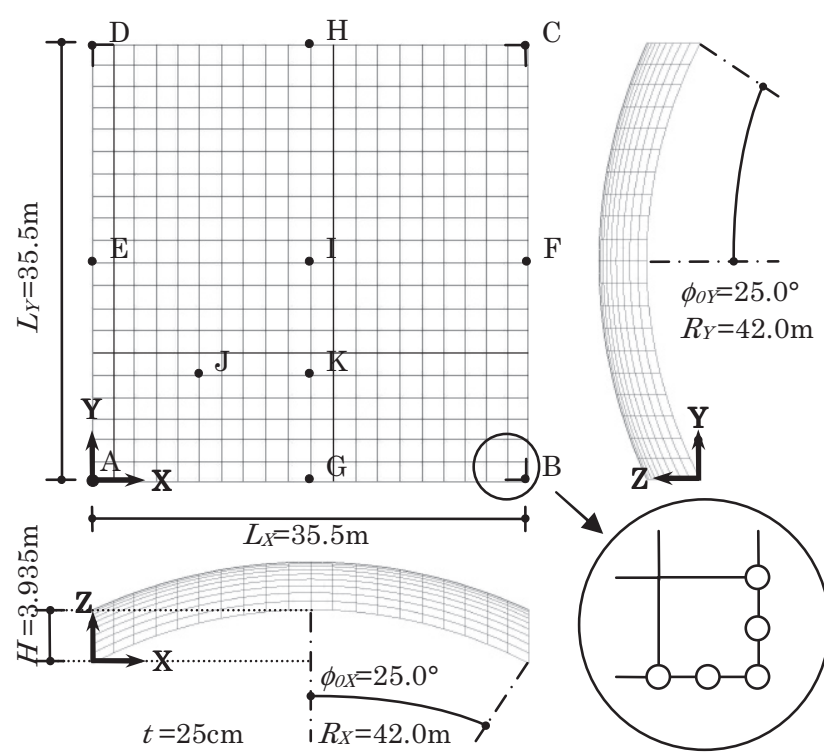

図1 シェルの形状および要素分割

を想定し, 矩形状で逆対称の鉛直荷重と一様な水平荷重を仮定する。 本来, 地震荷重は地震応答解析から設定す心゙きものであるが，こ こでは, 地震動が X 方向に作用寸ると想定し, 近似的に図 2 の分布 を設定する。等分布固定荷重を荷重 $I$, 鉛直震度 1.0 の矩形逆対称 の鉛直地震荷重を荷重 $\mathrm{II}$, 水平震度 +1.0 あるいは- 1.0 の水平地震

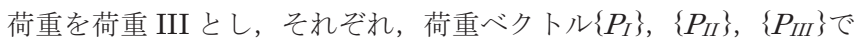
表す。これらの荷重は，4.2 節の場合を除いて，式(1)の倸数 $\mathrm{a}, \mathrm{b}$, $\mathrm{c}$ の比を変化させ，荷重係数 $\lambda$ をして同時に載荷する。

$$
\{P\}=\lambda\left[\mathrm{a}\left\{P_{I}\right\}+\mathrm{b}\left\{P_{I I}\right\}+\mathrm{c}\left\{P_{I I I}\right\}\right]
$$

なお荷重は節点荷重として各要素の 4 隅に作用させる（要素の辺の 中間節点には作用させない注 3$) ＼mathrm{~ 。 ~ R C ~ の 密 度 ~} \gamma=23.0 \mathrm{kN} / \mathrm{m}^{3}$, 要素支 配面積 $S=3.36 \mathrm{~m}^{2}$, 厚さ $t=25 \mathrm{~cm}$ を考慮して一般の内部の節点では $P_{I o}=19.32 \mathrm{kN}$ とする。外周は, その 2 分の 1 , 支持点はゼロとする。

\section{4 初期不整}

一般に弾性薄肉シェルは初期不整の分布が座屈モードに類似する と耐力は初期不整に敏感 7である。ここでは, 敏感性の検討のため, 式(2)，式(3)，図 3 に示寸初期不整分布を仮定寸る。

$$
\begin{aligned}
& W_{i}=W_{i 0} \sin \left(\frac{\pi x}{I_{X 0}}\right) \sin \left(\frac{\pi y}{I_{Y 0}}\right) \\
& W_{i}= \pm W_{i 0} \sin \left(\frac{3 \pi x}{2 I_{X 0}}\right) \sin \left(\frac{3 \pi y}{2 I_{Y 0}}\right)
\end{aligned}
$$

ただし, 本研究時点では座屈モードは不明であるので, 1 波および 1.5 波の分布を先験的に設定し，また，IASS 指針 7) で定める固定荷 重変位分布比例 (以下, 固定荷重比例型) も考慮し, 初期不整の耐力 に対する影響を分析する。ここで， $I_{X O} ， l_{Y O}$ は RC シェルの中央面の $\mathrm{X}, \mathrm{Y}$ 方向の弧の長さの半分とする。なお, 初期不整は曲面の鉛直 下向き方向を正と設定し, 最大振幅 $W_{i}$ は, 表 1 に示寸ようにシェ ル厚の $40 \%$ までの值を想定する。

\section{5 配筋之材料特性}

鉄筋は, バイリニアの履歴特性を仮定する。ヤング率 $E_{s}=205,000 \mathrm{~N} / \mathrm{mm}^{2}$, 降伏応力度 $\sigma_{y}=235 \mathrm{~N} / \mathrm{mm}^{2}$, ひずみ硬化係数 $E_{t}=2,050 \mathrm{~N} / \mathrm{mm}^{2}$ とする。配筋は, 図 $4(\mathrm{~b})$ に示すように, $x$ 方向, $y$ 方
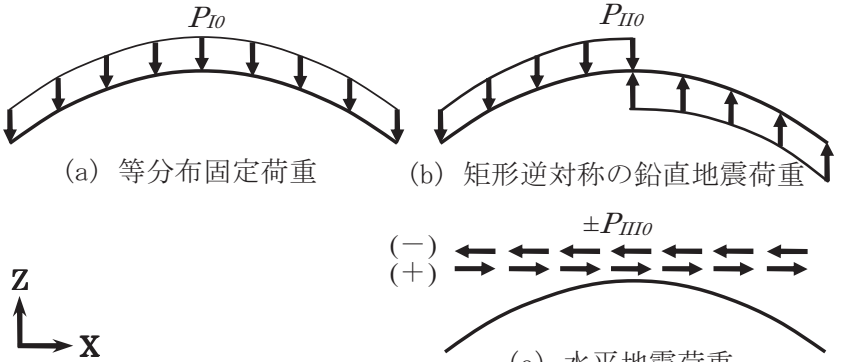

（c）水平地震荷重

図2作用荷重

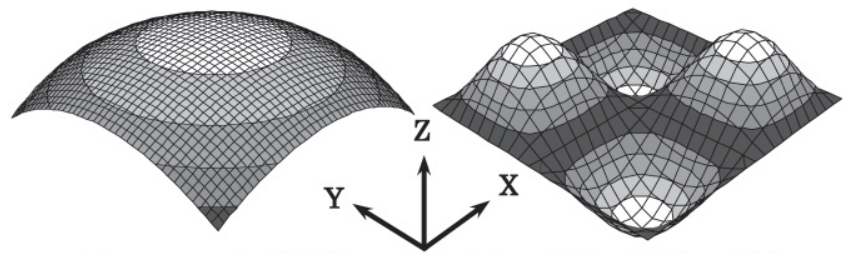

（a）シェルの初期形状

(b) 正弦波 1 波長 式(2)

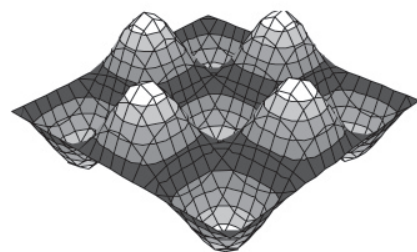

(c) 正弦波 1.5 波長 式(3)

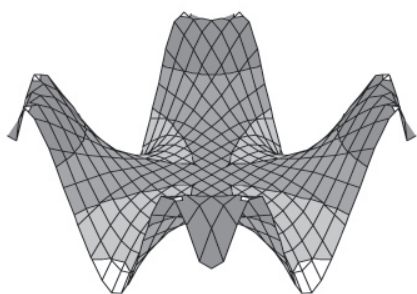

（e）固定荷重比例型

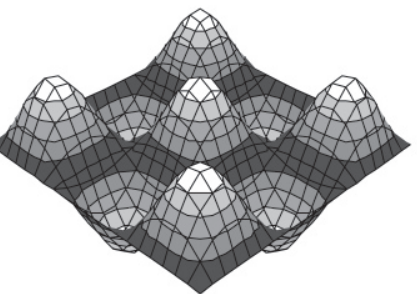

(d) 逆正弦波 1.5 波長 式(3)

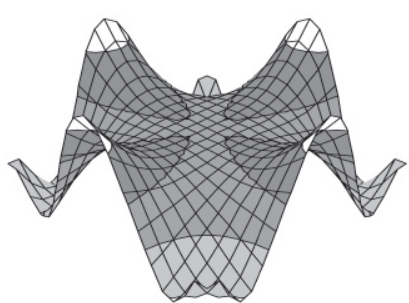

（f）固定荷重逆比例型
図3 初期不整

表 1 初期不整の大きさ

\begin{tabular}{|c|c|c|c|c|}
\hline イ記号 & $g_{O}$ & $g_{I I}$ & $g_{I I I}$ & $g_{I V}$ \\
\hline$W_{i O} / t$ & 0.00 & 0.10 & 0.20 & 0.40 \\
\hline$W_{i O}(\mathrm{~cm})$ & 0.00 & 2.50 & 5.00 & 10.0 \\
\hline
\end{tabular}

向ともに，上面，下面の鉄筋比は同じで $0.2 \%$ また $0.5 \%$ とする。 鉄筋中心位置は，上端・下端，主筋・配力筋ともコンクリート外面 から $5 \mathrm{~cm}$ とする。

\section{6 コンクリートの材料特性}

コンクリートの構成則は，環状格子モデル23,24)を用いる。図 5 に Kupfer ${ }^{29)}$ ほかによる降伏曲面注4) を示す。本研究では, 前述のよう に，コンクリートの引張強度がシェルの耐力等に与える影響の検討 も目的としているため, 眓 5 に示すように引張強度の異なる 2 種類 の構成則を用いる。なお, 本研究では, ヤング率 $\left(F_{C} / 3\right.$ 割線剛性 $)$ として $E_{c}=27,780 \mathrm{~N} / \mathrm{mm}^{2}$ を設定し, 環状格子モデルの部材特性を定 めた。なお，環状格子モデルの部材特性を用いた 1 軸引張強度は， 


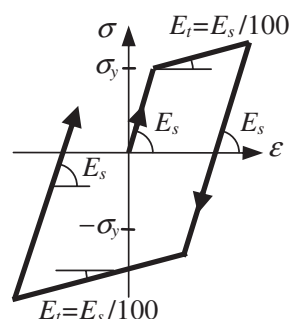

(a) 鉄筋の履歴特性

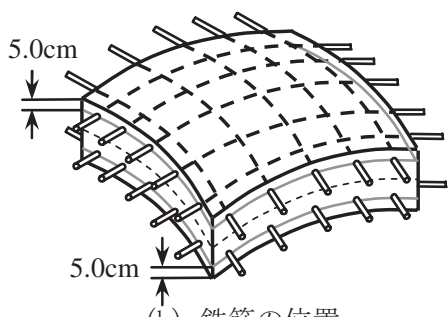

(b) 鉄筋の位置
図4 鉄筋の定義

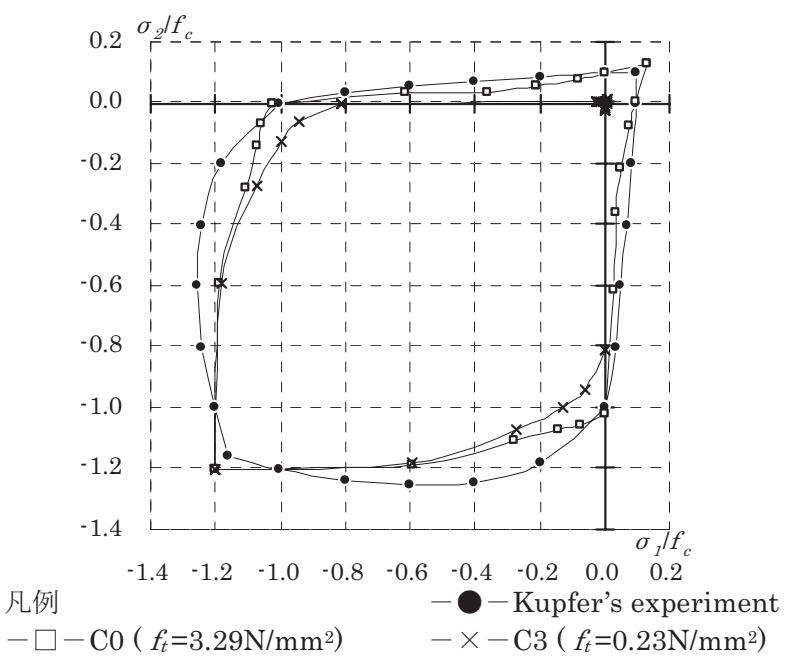

図5解析に用いたコンクリートの降伏曲面

構成則 $\mathrm{C} 0, \mathrm{C} 3$ 注 5) でそれぞれ $f_{t}=3.29 \mathrm{~N} / \mathrm{mm}^{2}, f_{t}=0.23 \mathrm{~N} / \mathrm{mm}^{2}$ であ り, $f_{t}=3.29 \mathrm{~N} / \mathrm{mm}^{2}$ は $F_{C} / 10$ にほぼ対応し, $f_{t}=0.23 \mathrm{~N} / \mathrm{mm}^{2}$ はコン クリートの引張強度がゼロの場合に相当する。また, 設定した環状 格子モデルの 1 軸圧縮強度は構成則 $\mathrm{C} 0$, C3 でそれぞれ $f_{c}=35.1 \mathrm{~N} / \mathrm{mm}^{2}, \quad f_{c}=30.2 \mathrm{~N} / \mathrm{mm}^{2}$ である。

\section{3. 等分布荷重時の耐力の分析}

固定荷重の場合, 式(1)で $\mathrm{a}=1.0, \mathrm{~b}=0.0, \mathrm{c}=0.0$ と置き, 耐力の初 期不整敏感性を検討する。

\section{1 初期不整とコンクリート引張強度の耐カへの影響}

最大荷重時の荷重係数 (以下, 耐力係数 $\lambda_{c r}$ ) を図 6(a), (b) と図 7(a),(b)に示す。縦軸が耐力係数，横軸が初期不整である。

（1）鉄筋比 $0.2 \%$ と $0.5 \%$ に共通して固定荷重比例型の初期不整の 場合, 耐力の低下が大きい。続いて, 逆正弦波 1.5 波長の初期不整 がやや大きい。(2) 一方, 正弦波 1.5 波長, 固定荷重逆比例型では, 初期不整が増すにつれて耐力が上昇する。（3）耐力の低下が最も大 きい固定荷重比例型に関しては, シェル厚の $40 \%$ の初期不整 $(10 \mathrm{~cm})$ があると，(3.1）鉄筋比が $0.2 \%$ で構成則 $\mathrm{C} 0$ では，初期不整が無い 場合に比べ， $\lambda_{c r}=2.55$ から $\lambda_{c r}=1.60$ 一と $63 \%$ まで低下し, 一方, 構 成則 C3 では， $\lambda_{c r}=1.85$ から $\lambda_{c r}=1.22$ へと $66 \%$ まで低下寸ることが 確認できる。また，（3.2）鉄筋比が $0.5 \%$ の場合，構成則 C0 と C3 ではそれぞれ， $\lambda_{c r}=2.82$ から $\lambda_{c r}=2.03$ 一と $72 \%$ まで， $\lambda_{c r}=2.52$ から $\lambda_{c r}=1.90$ 一と $75 \%$ まで耐力が低下寸る。(4) これらの結果から判断 すると, 仮定した 5 つの初期不整の分布では, 耐力の初期不整敏感 性は，弾性薄肉シェルほどは大きくないが，(5) シェル厚の $40 \%$ の 初期不整 $(10 \mathrm{~cm})$ 程度の初期不整があると耐力低下は無視できない。

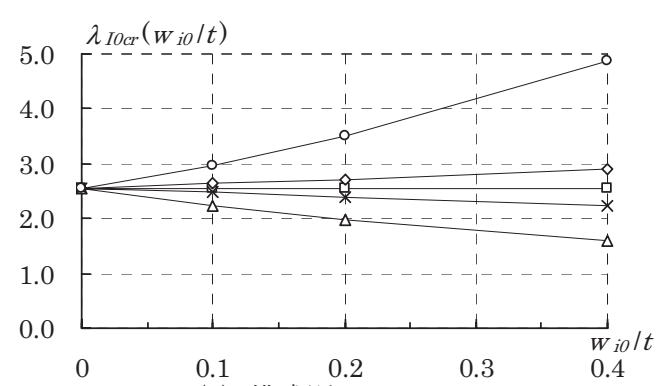

(a) 構成則 $\mathrm{C} 0, \mathrm{p}_{\mathrm{t}}=0.2 \%$

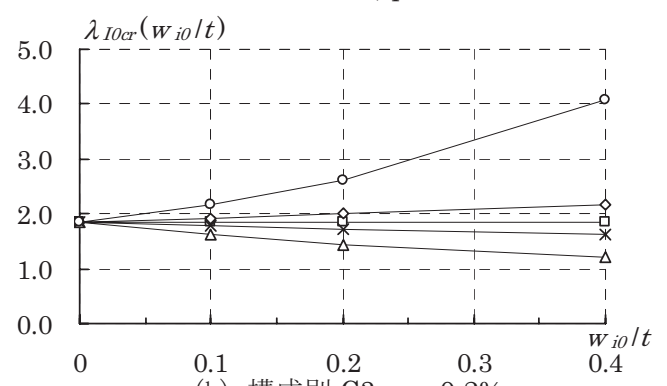

(b) 構成則 $\mathrm{C} 3, \mathrm{p}_{\mathrm{t}}=0.2 \%$

図6 初期不整敏感性（固定荷重），鉄筋比 $0.2 \%$
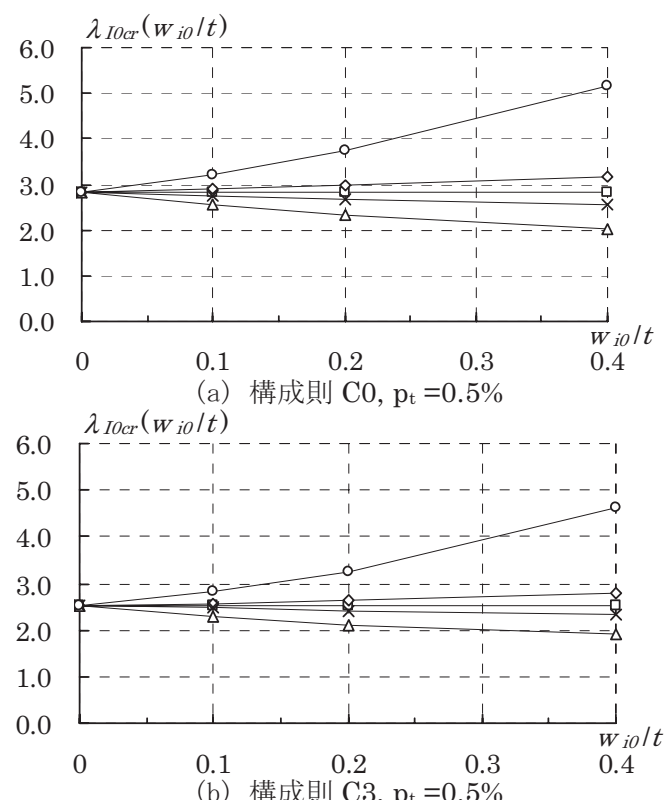

(b) 構成則 $\mathrm{C} 3, \mathrm{p}_{\mathrm{t}}=0.5 \%$

凡例 図 6(a),(b), 図 7(a),(b)共通 $-\square-$ 正弦波 1.0 波長

$-\diamond-$ 正弦波 1.5 波長

- $\times$ - 逆正弦波 1.5 波長

$-\triangle-$ 固定荷重比例型

- $\bigcirc$ - 固定荷重逆比例型

図7 初期不整敏感性（固定荷重），鉄筋比 $0.5 \%$

（6）初期不整が無く構成則 $\mathrm{C} 0$ の場合の耐力を基準とすると,コンク リートの引張強度の影響に関しては, (6.1) 鉄筋比 $0.2 \%$, 構成則 $\mathrm{C} 3$ では, 固定荷重比例型のシェル厚 $40 \%$ の初期不整 $(10 \mathrm{~cm})$ があると, 耐力は $\lambda_{c r}=2.55$ から $\lambda_{c r}=1.22$ 一と $48 \%$ まで低下寸る。(6.2) 鉄筋比 $0.5 \%$ ，構成則 C3 でシェル厚 $40 \%$ の初期不整 $(10 \mathrm{~cm})$ がある場合，耐 力は $\lambda_{c r}=2.82$ から $\lambda_{c r}=1.90$ へと $67 \%$ まで低下寸る。換言すれば，構 成則 $\mathrm{C} 0$ で初期不整が無い場合の耐力を基準にすると，構成則 C3, 固定荷重比例型でシェル厚 40\%の初期不整 $(10 \mathrm{~cm})$ があると, 耐力は 約半分まで低下し, 引張強度が低く, 鉄筋比が小さいほど, 耐力の 低下は大きくなる。 


\section{2 荷重·変位関係}

構成則 $\mathrm{C} 0$, 鉄筋比 $0.2 \%$ で初期不整が無い場合について, 点 $\mathrm{E}$, F， I，J，K の荷重と変位の関係を図 8 , また，荷重係数 $\lambda=1 / 3 \lambda_{c r}$, 耐力係数 $\lambda_{c r}$, および終局時の係数 $\lambda_{\text {end }}$ に対応する鉛直変位 $W$ を図 9 と図 10 に示す。なお，ここでは，便宜上，点 $\mathrm{E}, \mathrm{F}$ が $19 \mathrm{~cm}$ に至る 分岐変形直前を終局時とした。また，初期不整のある場合，あるい は, 構成則 C3 の場合の変形性状は, やや值が大きいが, 構成則 C0 で初期不整の無い場合と性状は類似となるので，特に説明しない。

（1）図 9, 図 10 から理解できるように, 鉛直変位の最大は外周の 辺のアーチの中央に生じ，耐力時までほぼ対称的な変形である。(2) また, 図 9 に示すように, 対角線 $\mathrm{AIC}$ と辺 $\mathrm{AGB}$ 等の外周のアーチ では，支持点の効果によりアーチ的な耐力機構となり，支持点から やや離れた近傍（図の記号 $\nabla ）$ で鉛直上向きの変位が生ずる。（3）図 8 に示すように, 耐力に至るまでは点 $\mathrm{E}$ と点 $\mathrm{F}$ の鉛直変位は対称変 形となっており，耐力以前には分岐型の変形は生じないが，(4) 耐 力後に点 $\mathrm{E}$ と $\mathrm{F}$ の鉛直変位がほぼ $19 \mathrm{~cm}$ で分岐型の変形が発生して いる。分岐後は点 $\mathrm{F}$ で鉛直下向きの変位が著しく増加し, 荷重が低 下寸る。(5) したがって, 文献 28)で述べたアーチでは, 図 3(b)のよ うな正弦波 1 波長の初期不整に敏感であったが，ここで対象とする 4 点支持形式では，これとは異なり，耐力が対称変形の下で生じた ので，耐力の初期不整敏感性は固定荷重比例型に関して大きい。(6) 固定荷重比例型の初期不整では, 曲げモーメントの発生が顕著に現 われ剛性低下により大変形が生じたと考えられる。

\section{3 断面力の性状}

構成則 $\mathrm{C} 0$, 鉄筋比 $0.2 \%$ で初期不整の無い場合について分析する。 なお，他の場合も，数值を除けば，ほぼ同様な傾向を示す。断面力 $N_{X}$ 等（図上では圧縮を負とする）を図 11 に示す。ただし, 要素内 の 9 個の積分点の平均を示す。(1) 4 点支持の特徴として, 周辺 $\mathrm{AGB}$, DHC で $N x$ が大きくなる。構造の対称性から $N y$ は, 辺 AED, BFC で大きくなる。(2) 図 11(a)から分かるように，ドーム中央部では， 耐力時に $3000 \mathrm{~N} / \mathrm{cm}$ (平均応力度 $120 \mathrm{~N} / \mathrm{cm}^{2}$ ) 程度となり, 膜応力 $3079 \mathrm{~N} / \mathrm{cm} （=\lambda_{c r} \times p \times R / 2, p=23 \mathrm{kN} / \mathrm{m}^{3} \times 0.25 \mathrm{~m}, \lambda_{c r}=2.55 ）$ にほぼ等 しく, 耐力時にも膜応力状態が保持されている。固定荷重に対して 0.85 倍の荷重 $\left(1 / 3 \lambda_{c r}\right)$ では, $N_{X}$ は圧縮 $1000 \mathrm{~N} / \mathrm{cm}$ であり, 膜応 力 $1026 \mathrm{~N} / \mathrm{cm}$ と同程度となり, 中央部の断面では, ほぼ応力と荷重 は線形関係にある。(3) 図 11(c)に示すように, アーチ形状の外周の 辺 AGB と辺 DHC 上では, 支持点から 2 3m の近傍において $N x$ は極めて大きく, 耐力時に約 $27000 \mathrm{~N} / \mathrm{cm}$ の圧縮力 (平均応力度 1080 $\left.\mathrm{N} / \mathrm{cm}^{2}\right)$ となる。対称性から外周の辺 $\mathrm{AED}, \mathrm{BFC}$ 上の支持点近傍 で $N y$ も大きくなる。（4）対角線上の断面 AIC ではアーチ作用が生 ずるので，支持点近傍の圧縮応力 $N_{X}$ が大きく，支持点の近傍では 固定荷重時に対して 0.85 倍の荷重では, 圧縮 $5000 \mathrm{~N} / \mathrm{cm}$ (平均応力 度 $200 \mathrm{~N} / \mathrm{cm}^{2}$ ), 耐力時に $N x$ は圧縮 $23800 \mathrm{~N} / \mathrm{cm}$ (平均応力度 $\left.952 \mathrm{~N} / \mathrm{cm}^{2}\right)$ となる。

耐力時の曲げモーメントについて分析する。曲げモーメント $M x$ （下側引張を正）等を図 12 に示寸。（1）耐力時までは， $M x$ 分布 の対称性が保持されている。なお, $M y$ も $M \mathrm{x}$ と同様に対称性が保 持されている。(2) 中央部の軸線 $\mathrm{EIF}$ 上では上面引張の $M \mathrm{x}$ を受け る。これは, 図 9(b)に示すように, 境界に補剛梁が無いため, 上に 凸の鉛直変位となるからである。(3) 図 12(b)に示すように, 対角線

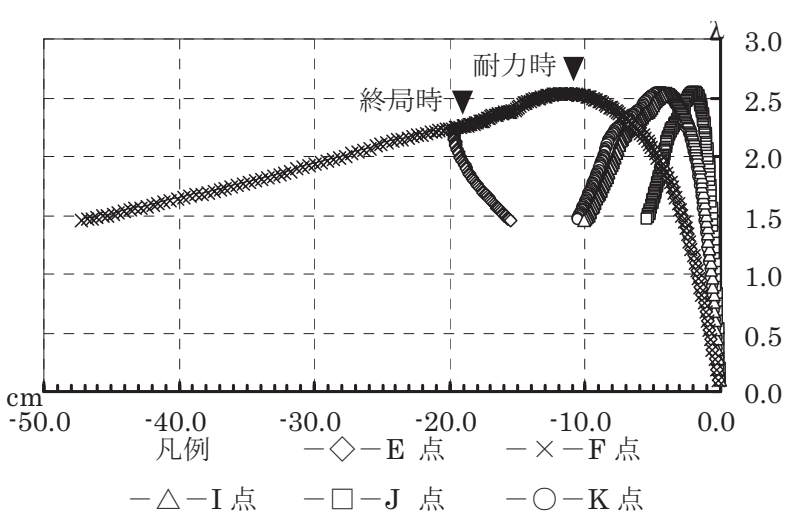

図8 荷重変位関係：構成則 $\mathrm{C} 0$, 鉄筋比 $0.2 \%$, 初期不整な

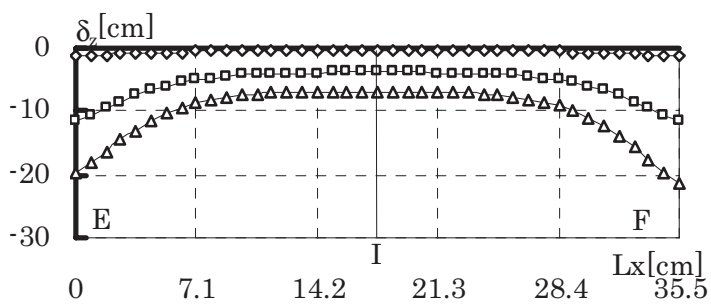

(a) 軸線 EIF

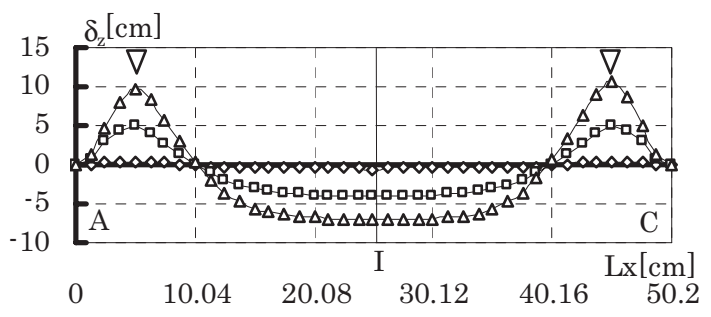

(b) 対角線 AIC

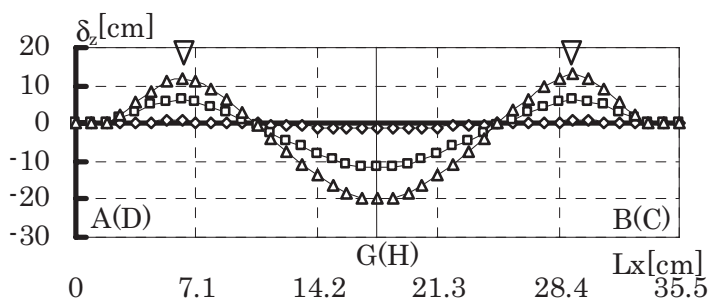

(c) 辺 AGB (辺 DHC もほぼ同じ)

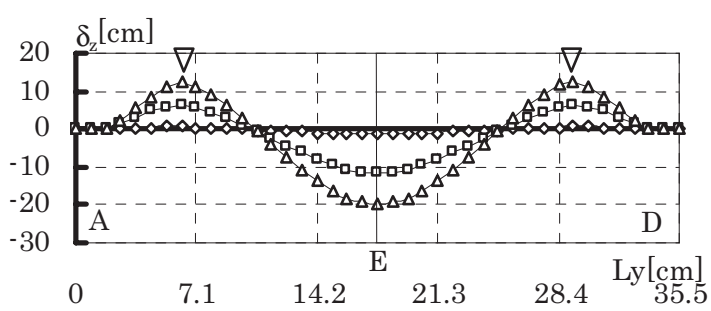

(d) 辺 AED

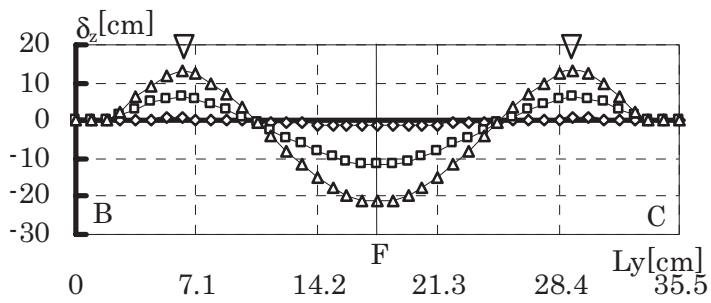

(e) 辺 $\mathrm{BFC}$

凡例 $-\diamond-1 / 3 \lambda_{c r} \quad-\square-\lambda_{c r} \quad-\triangle-\lambda_{\text {end }}$

図9 変位分布図：構成則 $\mathrm{C} 0$, 鉄筋比 $0.2 \%$, 初期不整なし 


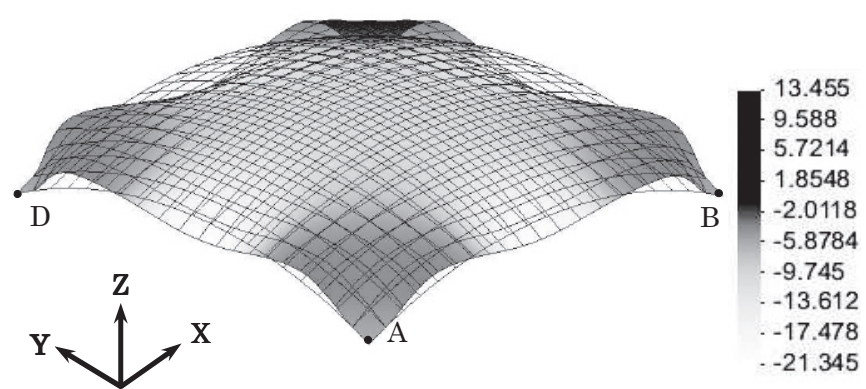

図10 変位分布図: 終局時[cm]（変形図の久変形倍率 10 倍） 構成則 $\mathrm{C} 0$, 鉄筋比 $0.2 \%$, 初期不整なし

$\mathrm{AIC}$ 上では, アーチ作用のため, 支持点から $2 \sim 3 \mathrm{~m}$ の近傍で鉛直 上向きに凸の変位となり, このため上面引張の曲げモーメントとな る。耐力時に最大で $62000 \mathrm{~N} \cdot \mathrm{cm} / \mathrm{cm}$ となり, 対称性から同様な值 の My となっている。（4）図 12(c)に示すように, 辺 AGB の支持点 から $5 \sim 6 \mathrm{~m}$ では, 上面引張の大きな $M x$ を受け, 耐力時には $140 \mathrm{kN}$. $\mathrm{cm} / \mathrm{cm}$ の值となる。この位置では, 図 11(c)で示すように, $M x$ と同 時に大きな圧縮力 $N x$ を受ける。このような状況は, 辺 DHC につ いても同様である。一方, 辺 $\mathrm{AGB}, \mathrm{DHC}$ のアーチ状の部分の中央 (点 $\mathrm{E}, \mathrm{F}, \mathrm{G}, \mathrm{H}$ の近傍) では, 図 11(c),(d)および図 12(c),(d),(e) に見るように，曲げモーメント，軸力ともにそれほど大きくない。 これは, シェル中央では荷重の多くが対角線 AIC, BID の方向に荷 重が負担されるからである。(5) 構造の対称性から, 辺 AED, BFC と辺 AGB，DHC では同様な応力分布となる。

\section{4 崩壊機構の分析}

構成則 $\mathrm{C} 0$, 鉄筋比 $0.2 \%$ で初期不整が無い場合について分析する。 3.3 節の分析によれば, 耐力時の断面力の性状は, 辺 AGB, DHC では, 支持点から $5 \sim 6 \mathrm{~m}$ の範囲で大きな圧縮軸力 $N x$ と曲げモーメ ント $M x$ (上面引張) を受ける。同様に辺 $\mathrm{AED}, \mathrm{BFC}$ では, 支持 点から 5 6m の範囲で大きな圧縮軸力 $N y$ と曲げモーメント $M y$ (上 面引張）を受ける。また, 外周のアーチ（たとえば，辺 AGB）の中 央では, 曲げモーメントはそれほど大きくなく, 軸力も小さい。こ れらの断面力により生ずるコンクリートの応力度を図 13 に，鉄筋 の応力度を図 14 に示す。ここで, 図 13 はコンクリートの上面と下 面位置における辺 $\mathrm{AGB}$ の主応力度の内, 圧縮度の大きい值 $\sigma_{2}$ を示 す。なお，辺 DHC，AED，BFC に関しても同様である。図 14 は 上面と下面の鉄筋の応力度であり, 辺 $\mathrm{AGB}, \mathrm{DHC}$ についてはX方 向 $\sigma_{1}$, 辺 $\mathrm{AED}, \mathrm{BFC}$ について $\mathrm{Y}$ 方向 $\sigma_{2}$ の鉄筋の応力度である。 変位増分法では強制的に変位を増加させるが，耐力以後は変位の 増加とともに荷重が低下寸る。この変位増分でひずみが増加し, 鉄 筋等の降伏が開始する。（1）変位の増分にしたがい, 図 14(c), (d)に 示す の位置で曲げモーメントが増加し，上面の鉄筋が降伏する。 これが原因でさらに外周の中央部で変位の増大をきたし, 図 14(a),(b)に示す $\nabla$ の位置で辺 AGB，DHC，AED，BFCのそれぞれ の辺方向の下面の鉄筋が降伏し崩壊する。ただし, 外周の中央部で は軸力 $\left(N_{x}\right.$ あるいは $\left.N_{y}\right)$ が極めて小さく, 対応する降伏モーメ ントも小さい。(2) 一方, コンクリートは, 図 13 に示すように耐力 時に支持部近傍で $2850 \mathrm{~N} / \mathrm{cm}^{2}$ になるものの, コンクリートの主応力 度は，設定した圧縮強度 $f_{c}=3510 \mathrm{~N} / \mathrm{cm}^{2}$ には至っていない。(3) 終 局時あるいは終局時以降には, 図 11(c),(d)の『に示すように, 外周

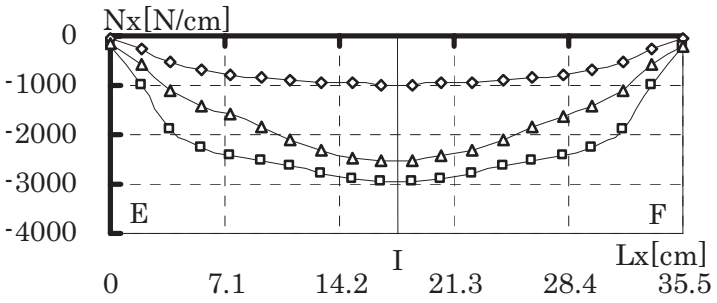

(a) 軸線 EIF

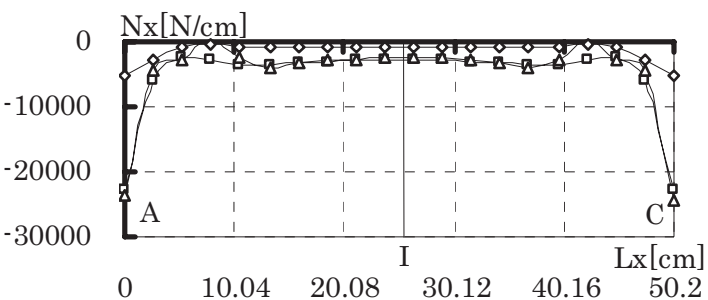

(b) 対角線 AIC

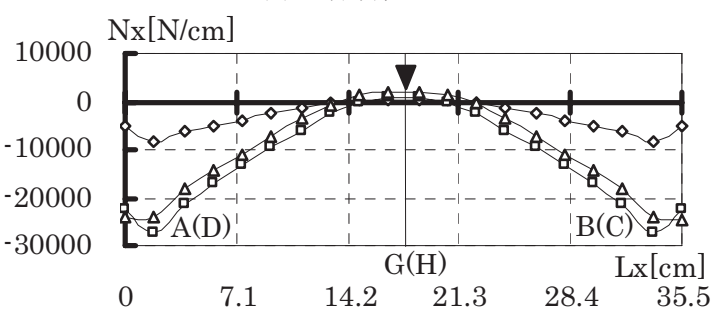

(c) 辺 $\mathrm{AGB}$ (辺 $\mathrm{DHC}$ もほぼ同じ)

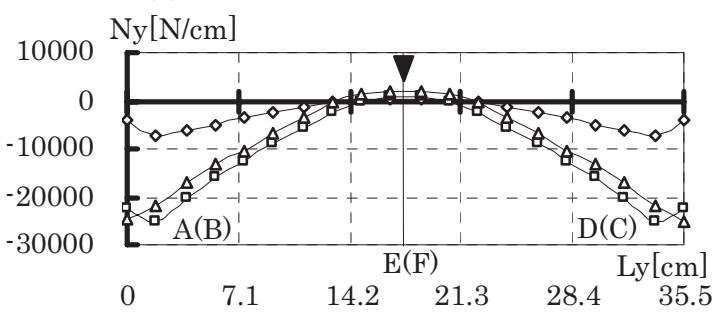

(d) 辺 AED (辺 BFC もほぼ同じ)

凡例 $-\diamond-1 / 3 \lambda_{c r} \quad-\square-\lambda_{c r} \quad-\triangle-\lambda_{\text {end }}$

図11 $N_{x}, N_{y}$ 分布図 : 構成則 $\mathrm{C} 0$, 鉄筋比 $0.2 \%$, 初期不整なし

の辺 AGB， AED の中央部では，下側引張の曲げモーメントを受け つつ，小さい軸力ではあるが，全断面が引張状態となる。したがっ て, この中央部では, 上面, 下面の鉄筋がともに引張応力場となり, 断面の剛性低下が起きている。このような分析によれば，(4) 図 14 (a) (d)の $\boldsymbol{\nabla}, \nabla の$ 位置で，曲げモーメントにより辺方向の鉄筋が降 伏したことが耐力を決定づけていると考えられる。つまり，初期不 整による付加曲げモーメントの増大, あるいは, 構成則 C3 のよう なコンクリートの引張耐力が小さい場合, 断面の剛性低下は, 図 6, 図 7 に示したように構造全体の耐力の低下, さらには図 8 に示すよ うな分岐型の変形が生じ, 崩壊につながることが理解できる。した がって,（5）図 6, 図 7 に示すように，鉄筋比が大きくなれば耐力 も大きいことから，外周辺の曲げ抵抗を高めることで耐力向上が期 待できる。外周辺に補剛梁を設置し，支持部近傍や中央部の曲げ性 能を高めること，また，支持点付近のシェル厚を増加させてコンク リートの応力度を低下させることで，耐力向上が可能となる。

\section{4. 固定荷重及び水平荷重, 逆対称鉛直荷重を受ける場合の分析}

3.4 節では, 過荷重になれば外周辺のアーチ部分で曲げモーメン トが増幅され鉄筋が降伏し，崩壞に至ることを確認した。地震のあ 


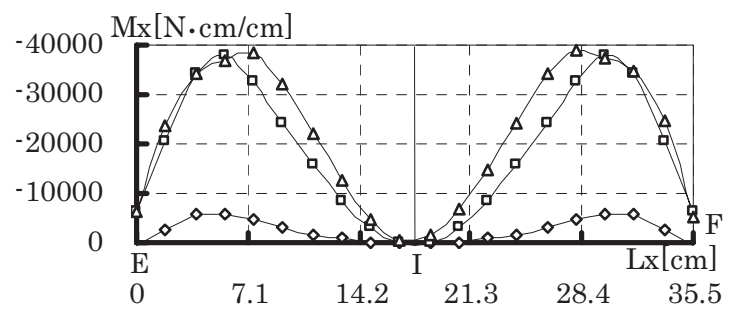

(a) 軸線 EIF

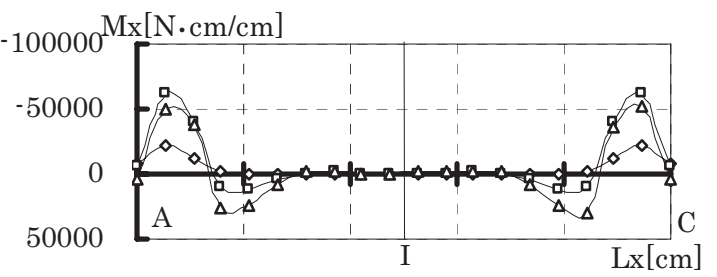

$\begin{array}{llllll}0 & 10.04 & 20.08 & 30.12 & 40.16 & 50.2\end{array}$

(b) 対角線 AIC

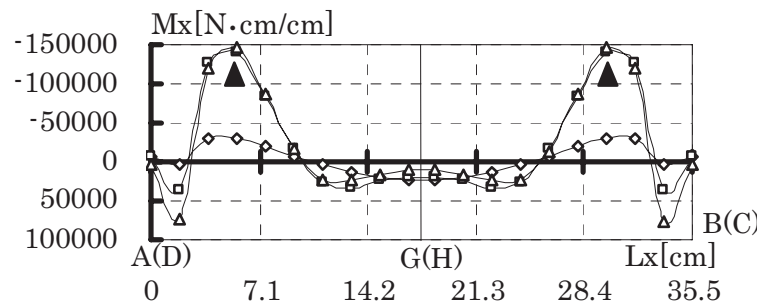

(c) 辺 $\mathrm{AGB}$ (辺 DHC もほぼ同じ)

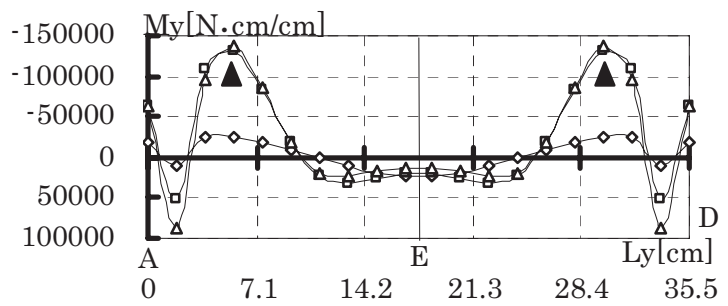

(d) 辺 AED

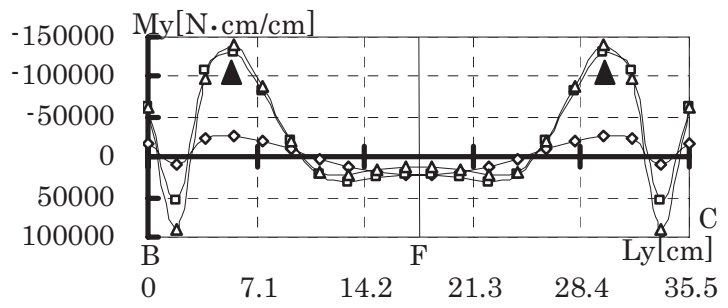

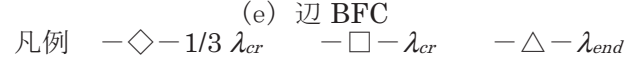

図12 $M x, M y$ 分布図: 構成則 $\mathrm{C} 0$, 鉄筋比 $0.2 \%$, 初期不整なし

る地域では，地震力による水平地震力だけでなく，大きな逆対称の 鉛直地震力が作用すると想定される。そこで，以下では，固定荷重 に加え, 前述のように, 近似的に設定した地震力に関して, 耐力相 関を検討する。

\section{1 逆対称鉛直荷重あるいは水平荷重を受ける場合}

固定荷重 $P_{I}$ と逆対称鉛直地震荷重 $P_{I I}$ の耐力相関, また, 固定荷 重 $P_{I}$ と水平地震荷重 $P_{I I I}$ （左から作用寸る場合を $\mathrm{c}=1.0$ とする）の 耐力相関をそれぞれ図 15 , 図 16 に示す。同図では初期不整は無い ものとし，構成則は $\mathrm{C} 0, \mathrm{C} 3$ を用い，鉄筋比は $0.2 \%$ と $0.5 \%$ を想定 する。なお， $P_{I}$ と $P_{I I}$ の相関では式(1)で $\mathrm{c}=0.0, P_{I}$ と $P_{I I I}$ の相関で は式(1)で $\mathrm{b}=0.0$ として解析している。

設計上は，固定荷重が作用している状態で水平地震荷重と逆対称

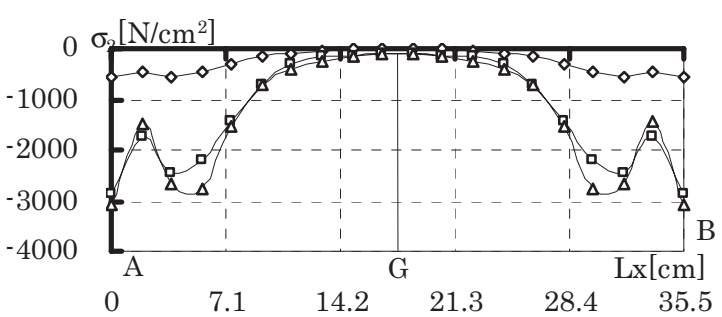

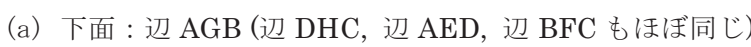

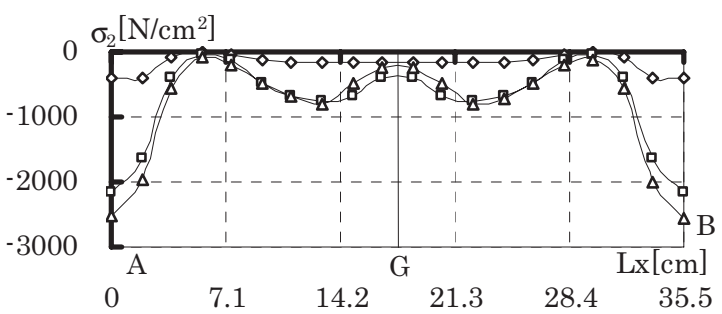

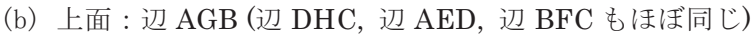

$$
\text { 凡例 }-\diamond-1 / 3 \lambda_{c r} \quad-\square-\lambda_{c r} \quad-\triangle-\lambda_{\text {end }}
$$

図13 コンクリート応力度 : 構成則 $\mathrm{C} 0$, 鉄筋比 $0.2 \%$, 初期不整なし

鉛直地震荷重が作用する場合が重要となる。

固定荷重が作用した状態（図 15 の横軸の值が 1.0）で（1）逆対 称の鉛直荷重時に, 構成則 $\mathrm{C} 3$ で鉄筋比 $0.2 \%$ あるいは $0.5 \%$ の構造 では，逆対称鉛直地震荷重は固定荷重の 0.61 あるいは 1.21 倍相当 までしか耐えることができない。(2) 構成則 $\mathrm{C} 0$ で鉄筋比 $0.2 \%$ ある いは $0.5 \%$ の構造では，逆対称鉛直地震荷重は固定荷重の 0.78 ある いは 1.32 倍相当までの耐力となる。この結果によれば, 逆対称の鈆 直地震力が静的震度で 1.0 程度必要な場合には, 鉄筋比として $0.5 \%$ 程度以上が必要となる。

一方，固定荷重が作用した状態（図 16 の横軸の值が 1.0）で，(3) 一様な水平地震荷重が作用寸る場合，コンクリートの構成則 C3 で 鉄筋比 $0.2 \%$ あるいは $0.5 \%$ の構造では, 水平地震荷重は固定荷重の 0.51 あるいは 1.02 倍相当までしか耐えることができない。(4) 構成 則 $\mathrm{C} 0$ で鉄筋比 $0.2 \%$ あるい $0.5 \%$ の構造には，水平地震荷重は固 定荷重の 0.81 あるいは 1.20 倍相当までの耐力となる。この結果に よれば, 水平地震力が静的震度で 1.0 程度必要な場合には, 鉄筋比 として $0.5 \%$ 程度以上が必要となる。

\section{2 固定荷重に加え逆対称鉛直荷重と水平荷重を受ける場合}

常時作用する固定荷重を載荷した状態で, 水平地震荷重と逆対称 鉛直地震荷重が作用した場合に対して，この後者 2 種類の荷重に対 する耐力相関を求める。荷重は，次式

$$
\{P\}=\mathrm{a}\left\{P_{I}\right\}+\lambda\left[\mathrm{b}\left\{P_{I I}\right\}+\mathrm{c}\left\{P_{I I I}\right\}\right]
$$

において, a を 0 から 1 まで増加させて固定荷重を作用させた後, これを一定に保ったまま 2 種類の地震荷重を作用させる。その場合, $\mathrm{b}$ と $\mathrm{c}$ の比を变えて計算する。図 17 で縦軸は逆対称鉛直地震荷重を 示す。水平地震荷重を X 軸で左から作用する場合は $\mathrm{c}$ が正の領域に 対応し, 水平地震荷重を $\mathrm{X}$ 軸で右から作用する場合は $\mathrm{c}$ が負の領域 に対応しており, 結果を図 17 の左側に示す。水平地震荷重と逆対 称鉛直地震荷重は，同位相と逆位相の場合が想定されるため，2 ケ ースの位相を想定した。

（1） X 軸の中央から左半分が下向きであるように逆対称鉛直地震 荷重を設定している。この場合, 図 17 によれば左からの水平地震 


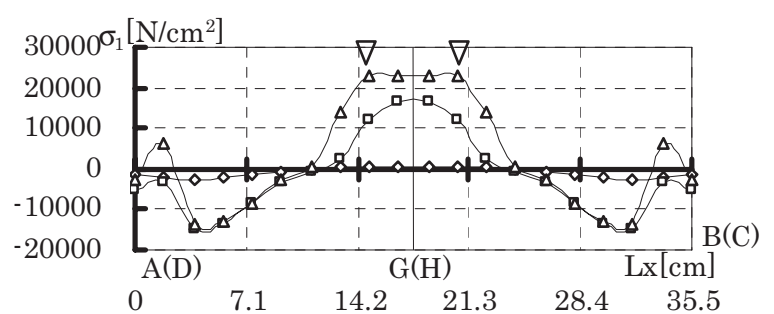

(a) 下面 : 辺 AGB (辺 DHC もほぼ同じ)

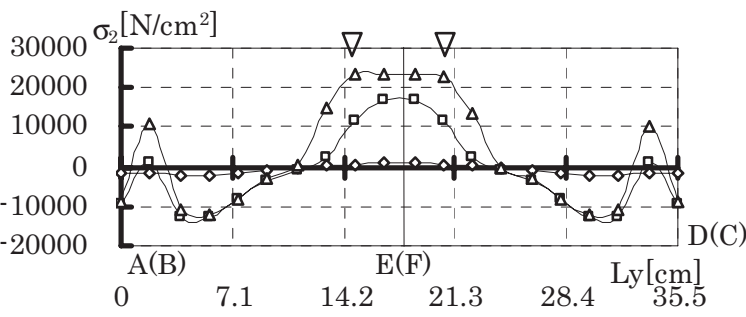

(b) 下面：辺 AED (辺 BFC もほぼ同じ)

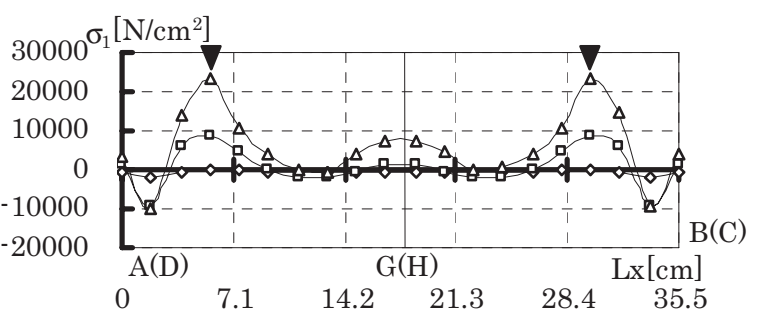

(c) 上面：辺 $\mathrm{AGB}$ (辺 $\mathrm{DHC}$ もほぼ同じ)

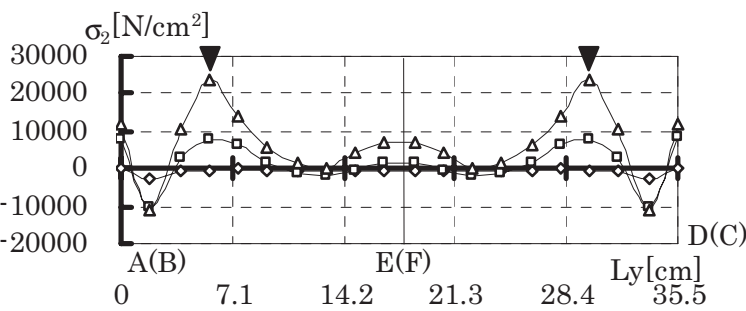

(d) 上面：辺 AED (辺 BFC もほぼ同じ)

凡例 $-\diamond-1 / 3 \lambda_{c r} \quad-\square-\lambda_{c r} \quad-\triangle-\lambda_{\text {end }}$

図 14 鉄筋応力度 : 構成則 $\mathrm{C} 0$, 鉄筋比 $0.2 \%$, 初期不整なし

荷重では，より左側の変形が増大し，地震荷重に対する耐力が低く なる。一方, 右からの水平地震荷重では, 逆対称の鉛直地震荷重の 効果を相殺し, 耐力が高くなる。(2) 実際の地震荷重は, ここで設 定した值, 分布とも当然異なり, また, 逆対称鉛直地震荷重と水平 地震荷重の位相関係も複雑であり, このような変形性状の分析や評 価にあっては, 実際に想定される地震力を用いた詳細な検討が必要 である。だたし, 図 17 の結果について控えめな評価をすれば, 構 成則 C3 で鉄筋比 $0.5 \%$ の場合には水平震度を 0.5 と寸れば, 耐えら れる逆対称の鋁直震度は, ほぼ 0.5 程度に過ぎない。(3) 4 点支持で 外周に補剛の無い構造の実績は国内ではないと思われるが，このよ うな構造に対して極めて概略的な地震力を仮定して検討した結果, 構成則 $\mathrm{C} 3$ で鉄筋比 $0.5 \%$ の場合には, 当該構造の耐震性は高くない 結果となった。 4 点支持形式が国内で建設される場合には外周で補 剛されると想定される。また, 形状探索技術の進歩した現在では, 耐震性の高い形状が探索 16,21 され，その形状が採用されると思われ る。これらの問題については, 今後の課題と考える。

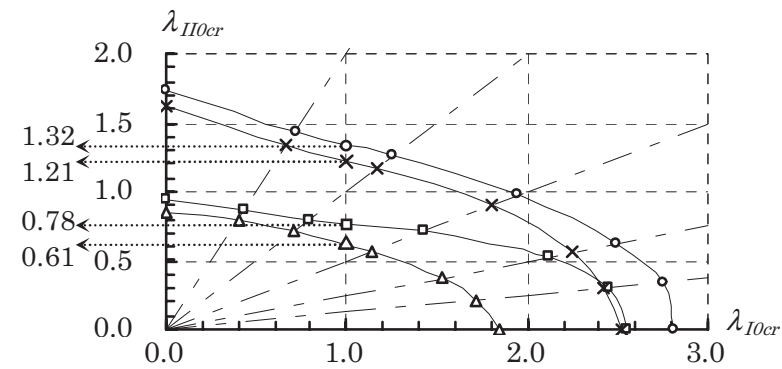

凡例 図 $15,16,17$ に共通

$$
\begin{array}{ll}
-\square-\mathrm{p}_{\mathrm{t}}=0.2 \%, \mathrm{C} 0 & -\triangle-\mathrm{p}_{\mathrm{t}}=0.2 \%, \mathrm{C} 3 \\
-\bigcirc-\mathrm{p}_{\mathrm{t}}=0.5 \%, \mathrm{C} 0 & -\times-\mathrm{p}_{\mathrm{t}}=0.5 \%, \mathrm{C} 3
\end{array}
$$

図15 耐力相関図(矩形状の逆対称鉛直地震荷重一等分布固定荷重)

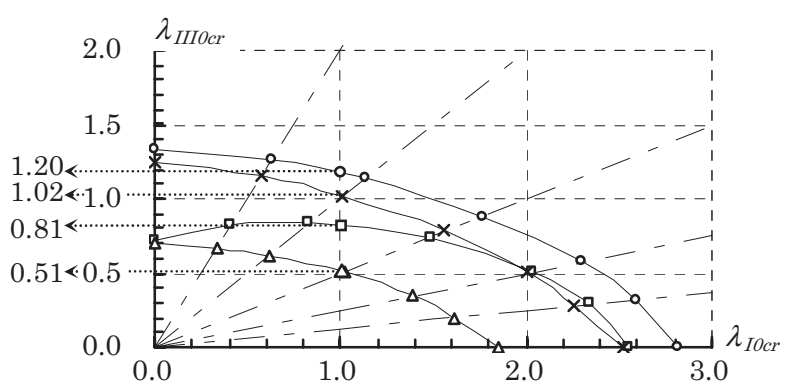

図16 耐力相関図(水平地震荷重一等分布固定荷重)

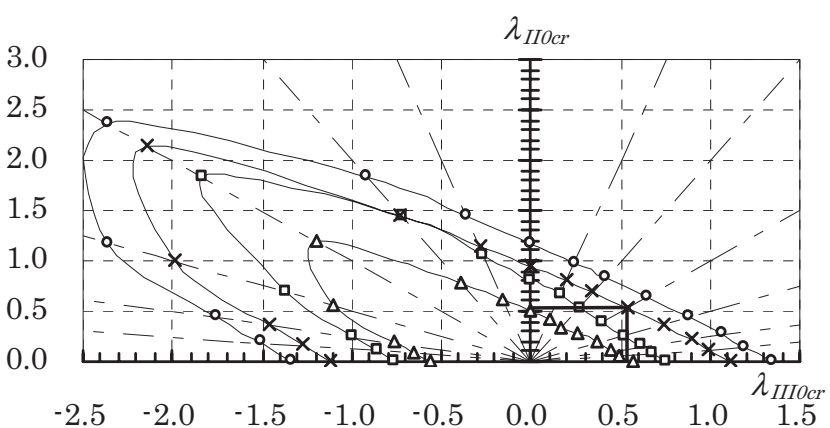

図17 而力相関図(逆対称鉛直荷重一水平荷重）固定荷重が常に作用

5. まとめ

本研究では, スパン $L=L_{X}=L_{Y}=35.5 \mathrm{~m}$, シェル厚 $t=25 \mathrm{~cm}$ の中 規模な 4 点支持 $\mathrm{RC}$ ドーム屋根に関して, 初期不整, コンクリート の引張強度，鉄筋比をパラメータとして，初期不整敏感性，固定荷 重と地震荷重の耐力相関を検討した。外周で補剛材が無く，かつ， 限定した構成則や鉄筋比の構造モデルに関する結果ではあるが，以 下に得られた知見をまとめる。

\section{1 固定荷重に対する検討結果}

（1）固定荷重時の耐力の初期不整敏感性は弾性薄肉シェル 7) ほど 大きくないが，固定荷重比例型の初期不整がシェル厚 $40 \%$ の場合， 鉄筋比 $0.2 \%$, 構成則 C3（引張強度がほぼゼロ）では，初期不整が 無く鉄筋比 $0.5 \%$ ，構成則 C0（引張強度が $\mathrm{Fc} / 10$ 程度）の場合の耐 力の $43 \%$ であり，初期不整，引張強度および鉄筋比による耐力低下 は無視できない。（2）対称的な変形の進行とともに，外周のアーチ 状部分の塑性化，特に，鉄筋の降伏とコンクリートの剛性低下によ り塑性変形が進行し, その後, 逆対称の変形が増大し, 崩壊に至る。

\section{2 固定荷重と地震荷重の耐力相関}

構成則 C3 の場合，鉄筋比 $0.5 \%$ 程度以上であれば，常時作用する 
固定荷重のもとで, 水平震度 0.5 程度, 逆対称の鉛直震度 0.5 程度 の地震力に耐えられると想定される。

\section{3 今後の検討項目}

ここで対象とした外周補剛の無い 4 点支持構造は, 固定荷重や地 震荷重に対して耐力はそれほど高くない。 RC シェルの耐力が自由 辺に沿う大きな曲げモーメントによる鉄筋降伏とコンクリートクラ ックによる剛性低下に左右される 22,30 )ことを勘案すると, 適切に外 周辺を補剛・配筋する必要がある。あるいは, Isler の実績 4)が示す ように, 固定荷重時に曲げモーメントが小さく圧縮が支配的な形状 とすることが重要となる。これらについては, 今後の課題としたい。 また, 地震力を極めて近似的に仮定したが, 今後は, 地震応答解析 による地震力の算定, 強地震動の下で幾何学的・材料的非線形を考 慮した地震応答性状分析が必要である。

今後は 4 点支持で 4 辺が補剛された場合, また, 曲げモーメント が小さくなるような探索形状に対して研究を展開する予定である。

\section{謝辞}

本研究に当たり, シェル・空間構造運営委員会において皆様から 貴重なご意見をいただき厚くお礼申し上げます。

\section{参考文献}

1) E. Torroja: The Structures of EDUARDOTOROJA, CEDEX 2000

2) B. P. Flecher: A History of Architecture, Charles Scriber's Sons, 1975 (The Palazzeto dello sport 1960)

3) N. Burger, D. P. Billington: Felix Candela, Elegance and Endurance: An Examination of The Xochimilco Shell, J. of IASS, Vol.47, No.3, pp.271-278, 2006

4) J. Chilton: Heinz Isler, Thomas Telford Ltd, 2000

5) 坪井善勝:曲面構造, 丸善 1965 坪井善昭: 建築知識別冊 第 2 集 建築 ノート 2 空間と構造フォルム，1980（東京カテドラル）

6）渡辺邦夫 : 木村俊彦の設計理念, 鹿島出版, 2000（福島県教育会館 1956 千葉県立文化会館 1967)

7) IASS : Recommendations for Reinforced Concrete Shells and Folded Plates, 1979

8) Y. Tsuboi : The Steel Framed Dome of the Tokyo International Trade Center, Proc.IASS, Colloquium on Hanging Roofs, Paris, pp.301-314, 1962

9）松下富士雄: 鉄骨立体構造理論と電子計算機, カラム No.18, pp98-100, 1966.4

10) Gr 8 British Standards Institution, BS 4485 Part4 1975: Specification for Water cooling towers, 1975

11) U. Wittek, W.B. Kratzig Natural Draught Cooling towers, A.A.BALKEMA, 1996

12）日本ガス協会：LNG 地上式貯槽指針，2002

13) 松岡理, 加藤史郎, 川島隆夫 : 偏平 HP シェルの数值解析, 日本建築学 会論文報告集 No.194, pp. 29-37, 1972.4

14）武藤厚，小山信夫，村田賢，加藤史郎：上載圧を受ける鉄筋コンクリー 卜球形シェルの非線形振動性状に関する検討 一複合非線形性を考慮し た数值解析手法と基本的な応答性状について一, 日本建築学会構造系論文 集 No.549, pp.83-90, 2001.11

15）高山誠, 中村博志, 加藤史郎 : 形状初期不整を有する鉄筋コンクリート 円筒シェルの破壊性状と最大耐力に関する実験と数值解析の比較, 日本 建築学会構造系論文報告集，第 429 号, pp.111-124, 1991.11 .

16）芦田泰成，林信実，高山誠：鉄筋コンクリート逆転懸垂型シェルの支持 条件に関する研究, 日本建築学会構造系論文集 No.544, pp.85-91, 2001.6

17）真下和彦, 野口昌也: 集中荷重を受ける RC 屋根形円筒シェルの耐力に関 する研究, 日本建築学会構造系論文集 No.474, pp.137-145, 1995.8
18）皆川洋一：水平梁を有する鉄筋コンクリート造円筒シェル屋根の終局耐 力:直交異方性円筒シェル屋根の解析と終局耐力評価式, 日本建築学会構 造系論文報告集 No.451, pp.111-121, 1993.9

19）日本建築学会連続体構造小委員会(シェル・空間構造運営委員会) : 鉄筋コ ンクリートシェル耐荷力実験資料 その 1 鉛直荷重を受ける部分円筒シ エル， 1993.3

20) 武藤厚，加藤友和，糠谷真理，平墳義正 : 鉄筋コンクリート造空間構造 の振動特性に関する評価の試み一既存アリーナにおける振動測定と数 值解析による振動特性の分析例一，日本建築学会構造系論文集 No.592 pp.113-119, 2005.6

21）中川智也, 芦田泰成, 高山誠, 半谷裕彦 : 鉄筋コンクリート任意形状シ エルの弾塑性性状, 日本建築学会構造系論文集 No.513, pp.127-134, 1998.11

22) M. Andres, R. Harte: Buckling of concrete Shells: A Simplified Numerical Approach, J. of IASS, Vol.47, No.3, pp.279-290, 2006

23) S. Kato, M. Ohya, T. Hara: Finite Element Analysis of Reinforced Concrete Shells under Cyclic Loading, J. of IASS, Vol.43, No.1, pp.23-40, 2002

24）加藤史郎, 大屋誠, 前田佐登男, 吉野文雄 : 放射・環状形格子モデルに よるコンクリートの構成方程式の定式化と RC シェルの有限要素解析へ の応用，構造工学論文集，Vol.44B, pp.441-454, 1998.3

25) 加藤史郎, 高山誠, 大屋誠, 島岡俊輔 : クランク型鉄筋コンクリート耐 震壁の有限要素解析, 構造工学論文集 Vol.48B, pp.119-127, 2002.3

26) S. J. Medwadowski: Buckling of Concrete Shells: An Overview, J. of IASS, Vol.45, No.1, pp.51-63, 2004

27) 武藤厚, 原隆，高山誠，真下和彦，佐々木睦郎， $\mathrm{RC}$ 曲面構造における複 合非線形挙動の予測に関する検証の試み—その 1 検証モデルによる実験 と解析の計画について一, 日本建築学会大会学術講演梗概集(九州). B-1, 構造 I, pp.737-738, 2007.8

28) S. Kato, R. Hara, S. Nakazawa, T. Hara, A. Muto: Ultimate Strength Evaluation of Reinforced Concrete Wide Arch Considering the Effects of Concrete Tensile Strength and Geometric Imperfections, Extended Abstract of IASS2010,pp.43-44, 2010

29) H. Kupfer, H.K.Hisdorf, H. Rush : Behavior of Concrete under Biaxial Stresses, ACI Journal, Vol.66, No.8, pp656-666, 1969

30）川崎健二郎，真下和彦，田中正史：修復された補強コンクリート造円筒 殻の耐力, ひび割れ形態と振動特性, 日本建築学会構造系論文集 Vo.73, No.628, pp.923-929, 2008.6

注

注1） RC シェル屋根の形状として円形平面，矩形平面，また，境界条件とし て全周ピン支持，単純支持などがある。円形平面で周辺がテンションリ ングで補剛されたもの（平面直径 $50 \mathrm{~m}$ ）は，すでに坪井により応力性状

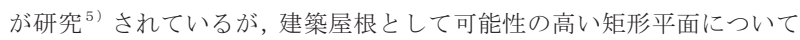
は, 弾塑性を考慮した研究は少ない。図 1 の矩形平面の場合, 4 辺で補 剛される場合が一般的であるが, 本研究では, その前段階として 4 辺に 補剛が無い場合の挙動の分析を進め, 問題点を明らかにすることとした。

注2）ロッキング現象およびゼロエネルギーモードの発生の危険性を回避す るため, 曲面要素として Heterosis 要素を使用した。

注3）等分布荷重として荷重を与えた場合と当該論文のように集中荷重とし て与えても，耐力，変位等は殆ど同じであった。

注4）本構成則は，内部構造を有する物理モデルの 1 種であるため，引張特性 と圧縮特性を全く違うものとして定めることが出来ない点もあり，環状 格子を構成するトラス要素の圧縮特性が同じでも, トラス要素の引張強 度が変化すると圧縮領域の降伏条件が変化する特性が現れる。特にコン クリートの引張強度を低くなるように格子部材の引張強度を低く設定 すると, コンクリートの 1 軸圧縮強度もやや低下寸る傾向が現れる。

注5）先の論文 28)で用いた構成則 $\mathrm{C} 0, \mathrm{C} 1, \mathrm{C} 2, \mathrm{C} 3$ と整合させるため, C0 と C3 と記号を附す。

(2011年 2 月 9 日原稿受理, 2011年 7 月 20 日採用決定） 